\title{
Microstructure and dielectric properties of dysprosium-doped barium titanate ceramics
}

\section{(Microestrutura e propriedades dielétricas de cerâmicas de titanato de bário dopado com disprósio)}

\author{
Y. Pu', W. Chen ${ }^{1}$, S. Chen ${ }^{1}$, Hans T. Langhammer ${ }^{2}$

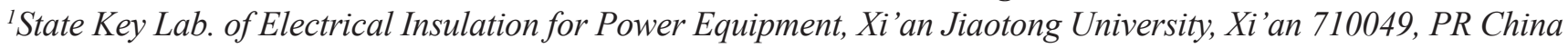 \\ ${ }^{2}$ Department of Physics, Martin-Luther-University Halle-Wittenberg, Halle/Saale, Germany
}

\begin{abstract}
The substitution behavior and lattice parameter of barium titanate between solid-solubility with a dopant concentration in the range of 0.25 to $1.5 \mathrm{~mol} \%$ are studied. The influences of dysprosium-doped fraction on the grain size and dielectric properties of barium titanate ceramic, including dielectric constant and breakdown electric field strength, are investigated via scanning electronic microscopy, X-ray diffraction and electric property tester. The results show that, at a dysprosium concentration of $0.75 \mathrm{~mol} \%$, the abnormal grain growth is inhibited and the lattice parameters of grain rise up to the maximum because of the lowest vacancy concentration. In addition, the finegrain and high density of barium titanate ceramic result in its excellent dielectric properties. The relative dielectric constant $\left(25^{\circ} \mathrm{C}\right)$ reaches to 4100 . The temperature coefficient of the capacitance varies from -10 to $10 \%$ within the temperature range of $-15^{\circ} \mathrm{C}-100{ }^{\circ} \mathrm{C}$, and the breakdown electric field strength (alternating current) achieves $3.2 \mathrm{kV} / \mathrm{mm}$. These data suggest that our barium titanate could be used in the manufacture of high voltage ceramic capacitors.
\end{abstract}

Keywords: dysprosium doping, microstructure and properties, barium titanate ceramic.

\begin{abstract}
Resumo
Foram estudados o comportamento da substituição e o parâmetro de rede de titanato de bário da solubilidade sólida com uma concentração de dopante na faixa 0,25-1,5 mol\%. As influências da fração do dopante disprósio no tamanho de grão e nas propriedades dielétricas da cerâmica de titanato de bário, incluindo constante dielétrica e rigidez dielétrica foram investigadas por meio de microscopia eletrônica de varredura, difração de raios X e teste de propriedades elétricas. Os resultados mostram que a uma concentração de disprósio de 0,75 mol\% o crescimento anormal de grão é inibido e os parâmetros de rede aumentam até um máximo devido a menor concentração de vacâncias. Além disso, as cerâmicas de grãos pequenos e alta densidade resultam em excelentes propriedades dielétricas. A constante dielétrica relativa $\left(25^{\circ} \mathrm{C}\right)$ atinge um valor de 4100. O coeficiente de temperatura da capacitância varia de -10 a $10 \%$ na faixa de temperatura de $-15^{\circ} \mathrm{C}$ a $100^{\circ} \mathrm{C}$, e o valor de rigidez dielétrica (corrente alternada) atinge $3,2 \mathrm{kV} / \mathrm{mm}$. Estes resultados sugerem que o titanato de bário preparado pode ser usado na fabricação de capacitores de alta voltagem.

Palavras-chave: dopagem com disprósio, microestrutura e propriedades, cerâmica de titanato de bário.
\end{abstract}

\section{INTRODUCTION}

With the development of mixed integrated circuits, miniaturization of the high voltage ceramic capacitors components used in the high voltage outlets would be of desirable. In the past, the breakdown voltage was raised mainly by using capacitors with increased thickness. A more effective way is to use barium titanate $\left(\mathrm{BaTiO}_{3}\right)$ based ceramic material with high dielectric properties as the capacitor. When doped with some rare earth oxides, $\mathrm{BaTiO}_{3}$ powder could achieved a high dielectric constant and breakdown electric field strength. Commercial $\mathrm{BaTiO}_{3}$ powder are synthesized usually by solid phase reaction or by chemical precipitation after calcination at high temperatures. Such synthesized $\mathrm{BaTiO}_{3}$ powder have a limited size range, microstructural variance, nonstoichiometric composition, and poor electric reproducibility. Hydrothermal fabrication method, instead, can result in tetragonal sub-micrometer $\mathrm{BaTiO}_{3}$ powder with high-purity, complete crystallization, and without agglomeration. Particularly, the doping with rare earth oxides can restrain the abnormal grain growth. thus improve the dielectric properties $[1,2]$.

Hennings [3], Kishi [4], Makovec [5] and Venigalla [6] have investigated the rare earth $(\mathrm{Ho}, \mathrm{Y}, \mathrm{Sm}, \mathrm{La})$ incorporation into $\mathrm{BaTiO}_{3}$. The starting powder they used were prepared by solid phase reaction or introducing additional elements $(\mathrm{Mg}$, $\mathrm{Zr}$ ) into the composition. Also, most of them use the powder to manufacture low-voltage layer capacitors and PTCR ceramic. Fabrication of $\mathrm{BaTiO}_{3}$ powder by hydrothermal method, as well as their application in high-voltage ceramic capacitors, has not been reported so far. The aim of our research is to achieve the high dielectric constant and breakdown electric field strength of ceramic capacitors. In this paper, the effects of Dy-doping on microstructure and dielectric properties 
of $\mathrm{BaTiO}_{3}$ ceramic were investigated and the environmentfriendly ceramic capacitor composition without lead $(\mathrm{Pb})$ in electronic device industry was developed.

\section{EXPERIMENTAL}

The crystalline $\mathrm{BaTiO}_{3}$ powder was prepared by the hydrothermal method (FengHua High-Tech Group Company, China). Impurity mass fraction was $0.02 \%$. The particle size of the powder was determined by SEM (Philips XL20, Netherlands). The specific surface area was measured by the single-point BET method with liquid $\mathrm{N}_{2}$ (Flowsorb 2300, Micromeritics Instrument Corp., Norcross, GA), and phase composition was analyzed using XRD (D/max-2200 PC, Rigaku Co. Ltd., Tokyo, Japan).Parameters of physical properties of powder were listed in Table I. $\mathrm{Dy}_{2} \mathrm{O}_{3}$ (REO-04, Asian Light Trade Co., Ltd, China).

Table I - Parameters of physical properties of $\mathrm{BaTiO}_{3}$ powder. [Tabela I - Parâmetros das propriedades físicas do BaTiO ${ }_{3}$.]

\begin{tabular}{ll}
\hline Physical properties & Parameters \\
\hline Particle size & $0.35 \mu \mathrm{m}$ \\
Specific surface area & $3.7 \mathrm{~m}^{2} / \mathrm{g}$ \\
Crystal phase & Tetragonal \\
\hline
\end{tabular}

$\mathrm{BaTiO}_{3}$ and $\mathrm{Dy}_{2} \mathrm{O}_{3}$ powders were weighed according to the chemical formula $\mathrm{Ba}_{1-\mathrm{x}} \mathrm{Dy}_{\mathrm{x}} \mathrm{TiO}_{3}$ and mixed for $24 \mathrm{~h}$ using stabilized zirconia balls in ethanol media. After being dried, the powder was granulated using ploy(vinyl alcohol) (PVA) binder and formed under a uniaxial pressure of $1000 \mathrm{~kg} / \mathrm{cm}^{2}$, and pressed pellets $(\phi 14 \mathrm{~mm} \times 2 \mathrm{~mm})$ were sintered at $1275^{\circ} \mathrm{C}$ for $2 \mathrm{~h}$ in air with a heating rate of $10^{\circ} \mathrm{C} / \mathrm{min}$. The average grain size was measured by the interception method on the fracture surfaces of sintered samples observed by SEM (JSM-5800, JEOL, Tokyo, Japan). At least 300 grains were measured to obtain the average grain size value. Lattice parameters of crystalline $\mathrm{BaTiO}_{3}$ was tested by XRD (D/max-2200 PC, Rigaku Co. Ltd., Tokyo, Japan) with a nickel-filtered $\mathrm{CuK} \alpha$, at a scan speed of $2 \%$ min,with a $0.02^{\circ}$ sampling step. The dielectric properties were measured using a permittivity analyzer with testing voltage of $1 \mathrm{~V}$ and a frequency of $1 \mathrm{kHz}$.

\section{RESULTS AND DISCUSSION}

In an ideal cubic perovskite, the ionic radii, $\mathrm{r}_{\mathrm{i}}(\mathrm{i}=A, B, O)$, obey the relation: $\left(r_{A}+r_{O}\right)=\sqrt{2}\left(r_{B}+r_{O}\right)$. The Goldschmidt tolerance factor for perovskite is defined by [7] :

$$
\mathrm{t}=\left(\mathrm{r}_{\mathrm{A}}+\mathrm{r}_{\mathrm{O}}\right) / \sqrt{2}\left(\mathrm{r}_{\mathrm{B}}+\mathrm{r}_{\mathrm{O}}\right)
$$

The dysprosium ionic radii was taken from CRC [8], $\mathrm{r}\left(\mathrm{Dy}_{V}^{3+}\right)=0.91 \times 10^{-10} \mathrm{~m}$, the subscript represents the coordination number. Tsur [9] suggested that the ion, when $0.87 \times 10^{-10} \mathrm{~m} \leq \mathrm{r}\left(\mathrm{R}_{V}^{3+}\right) \leq 0.94 \times 10^{-10} \mathrm{~m}$, was called amphoteric ion. This means that intermediate ions would occupy both Asite and B-site with different partitioning for each ion. Fig. 1 showed the room temperature resistivity of $\mathrm{BaTiO}_{3}$ ceramics doped with Dy as a function of dopant concentration. When the concentration of Dy is low, A-site is substituted by Dy ion, so substitution mechanism reaction equation is:

$\mathrm{xDy}^{3+}+\mathrm{BaTiO}_{3} \rightarrow\left(\mathrm{Ba}^{2+}{ }_{1-\mathrm{x}} \mathrm{Dy}_{\mathrm{x}}^{3+}\right)\left[\mathrm{Ti}^{4+}{ }_{1-\mathrm{x}}\left(\mathrm{Ti}^{4+} \cdot \mathrm{e}\right)_{\mathrm{x}}\right] \mathrm{O}_{3}+\mathrm{xBa}^{2+}$

When Dy ion occupies Ba-site, $\mathrm{Ti}^{4+}$ is reduced to $\mathrm{Ti}^{3+}$ and formed a conduction electron $\left(\mathrm{Ti}^{4+} \bullet \mathrm{e}\right)$ in order to keep charge neutrality. Subsequently, the resistivity of ceramic decreases sharply. The critical dopant concentration, causing the resistivity anomaly, was $0.4 \mathrm{~mol} \%$, slightly higher than $0.3 \mathrm{~mol} \%$ (see [10]), Possible reason for this is that the starting $\mathrm{BaTiO}_{3}$ powder has a high initial specific surface energy. Dy can substitute both $\mathrm{Ti}^{4+}$ and $\mathrm{Ba}^{2+}$ with a higher dopant level, $0.75 \mathrm{~mol} \%$. At the same time, Dy is an acceptor, so the charge is compensated to result in high resistivity.

The compensation mechanism reaction is:

$\mathrm{xDy}^{3+}+\mathrm{BaTiO}_{3} \rightarrow \mathrm{Ba}^{2+}{ }_{1-\mathrm{x} / 2} \mathrm{Dy}^{3+}\left(\mathrm{Ti}^{4+}{ }_{1-\mathrm{x} / 2}\right) \mathrm{O}_{3}+\mathrm{x} / 2 \mathrm{Ba}^{2+}+\mathrm{x} / 2 \mathrm{Ti}^{4+}$

The X-ray diffraction peaks of (111), (200) and (002) planes of $\mathrm{BaTiO}_{3}$ ceramic doped with different fraction of $\mathrm{Dy}_{2} \mathrm{O}_{3}$ are shown in Fig. 2.

The XRD pattern suggests that phase composition was tetragonal $\mathrm{BaTiO}_{3}$ grain. Lattice parameter determined by XRD results and the differences between unit cell parameters and unit cell volume difference were shown in Fig.3. Dy ${ }^{3+}$ enters

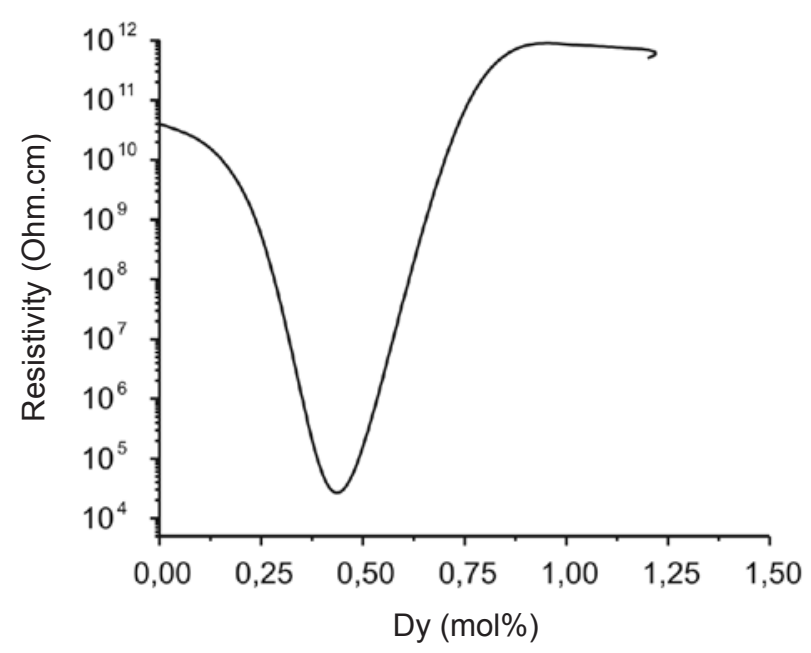

Figure 1: Electrical resistivity of $\mathrm{BaTiO}_{3}$ ceramic sintered at $1275^{\circ} \mathrm{C}$ as a function of Dy content.

[Figura 1: Resistividade elétrica da cerâmica de $\mathrm{BaTiO}_{3}$ sinterizada a $1275^{\circ} \mathrm{C}$, em função do teor de disprósio.] 


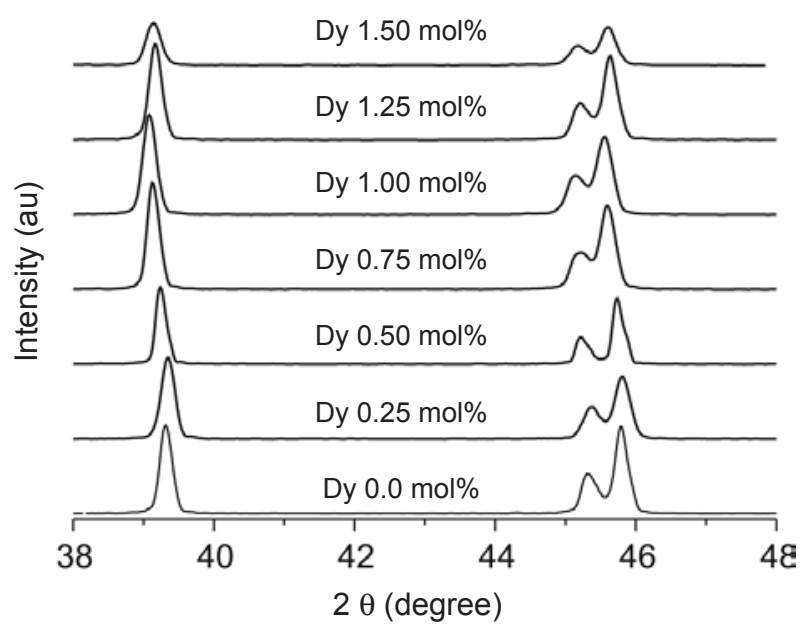

Figure 2: XRD pattern of (111), (200) and (002) plane of $\mathrm{BaTiO}_{3}$ ceramic doped with different fractions of $\mathrm{Dy}_{2} \mathrm{O}_{3}$.

[Figura 2: Difratograma de raios $X$ dos planos (111), (200) e (002) da cerâmica de $\mathrm{BaTiO}_{3}$ dopada com diferentes teores de $\mathrm{Dy}_{2} \mathrm{O}_{3}$.]

the crystal lattice and occupies the Ba-site at lower substitution content. As the atomic radius of $\mathrm{Dy}^{3+}\left(\mathrm{R}_{[\mathrm{B}]}=0.091 \mathrm{~nm}\right)$ is larger than that of to $\mathrm{Ti}^{4+}\left(\mathrm{R}_{[\mathrm{B}]}=0.068 \mathrm{~nm}\right)$, samples containing Dy on $\mathrm{B}$ sites show a continuous increase in the lattice constants. The maximum solubility of Dy on B-sites is up to ca. 9 mol \% [11]. Similarly, the small ionic radius of $\mathrm{Dy}^{3+}$ on A-sites $\left(\mathrm{R}_{[\mathrm{A}]}=0.117 \mathrm{~nm}\right)$ compared to $\mathrm{Ba}^{2+}\left(\mathrm{R}_{[\mathrm{Ba}]}=0.134 \mathrm{~nm}\right)$ causes a slight decrease in the lattice parameters of $\mathrm{BaTiO}_{3}$ with $\mathrm{Dy}^{3+}$ on A-sites. The lattice parameters of $\mathrm{BaTiO}_{3}$ containing $\mathrm{Dy}^{3+}$ both on A- and B-sites are between those of the above cases.

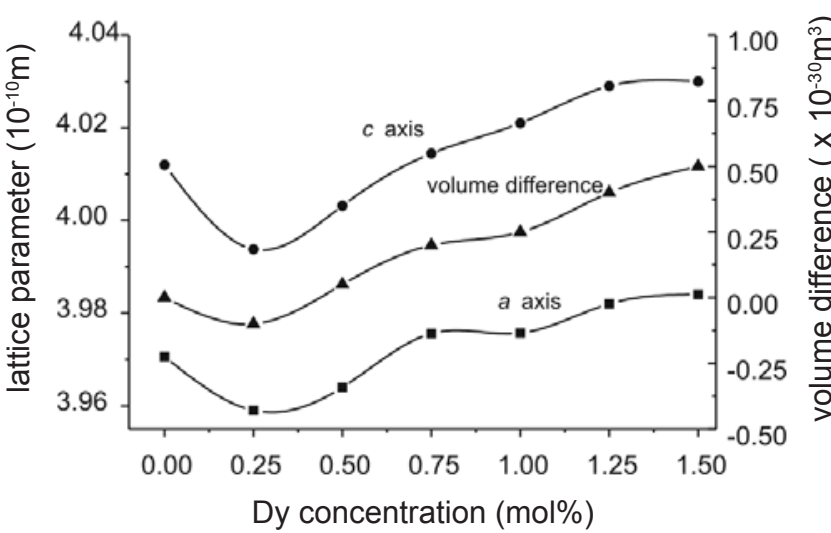

Figure 3: Lattice parameter and volume difference of Dy-doped $\mathrm{BaTiO}_{3}$ ceramic.

[Figura 3: Parâmetro de rede e diferença de volume da cerâmica de $\mathrm{BaTiO}_{3}$ dopada com Dy.]

Fig. 3 shows that, with increasing Dy concentration the lattice parameter of the perovskite $c$ axis increases more obviously than that of the $a$ axis. This can indicate that $\mathrm{Ti}^{4+}$ has a large moving space in $\left[\mathrm{TiO}_{6}\right]$ and a dramatic lattice distortion occurs after being doped with $\mathrm{Dy}_{2} \mathrm{O}_{3}$.

When $\mathrm{Dy}^{3+}$ subititutes $\mathrm{Ba}^{2+}$ and $\mathrm{Ti}^{4+}$, the differences in radii and valence of $\mathrm{Dy}^{3+}, \mathrm{Ba}^{2+}$ and $\mathrm{Ti}^{4+}$ will lead to variance in the vacancy concentration in crystals in order to compensate the charge. Generally, the energy needed for the incorporation of a dopant ion onto an individual lattice site in complex oxides is related to distortions (different in ionic radii), and to the formation of compensating defects during the incorporation of aliovalent ions (different in valence) [5]. Therefore, the solubility at the two different lattice sites of
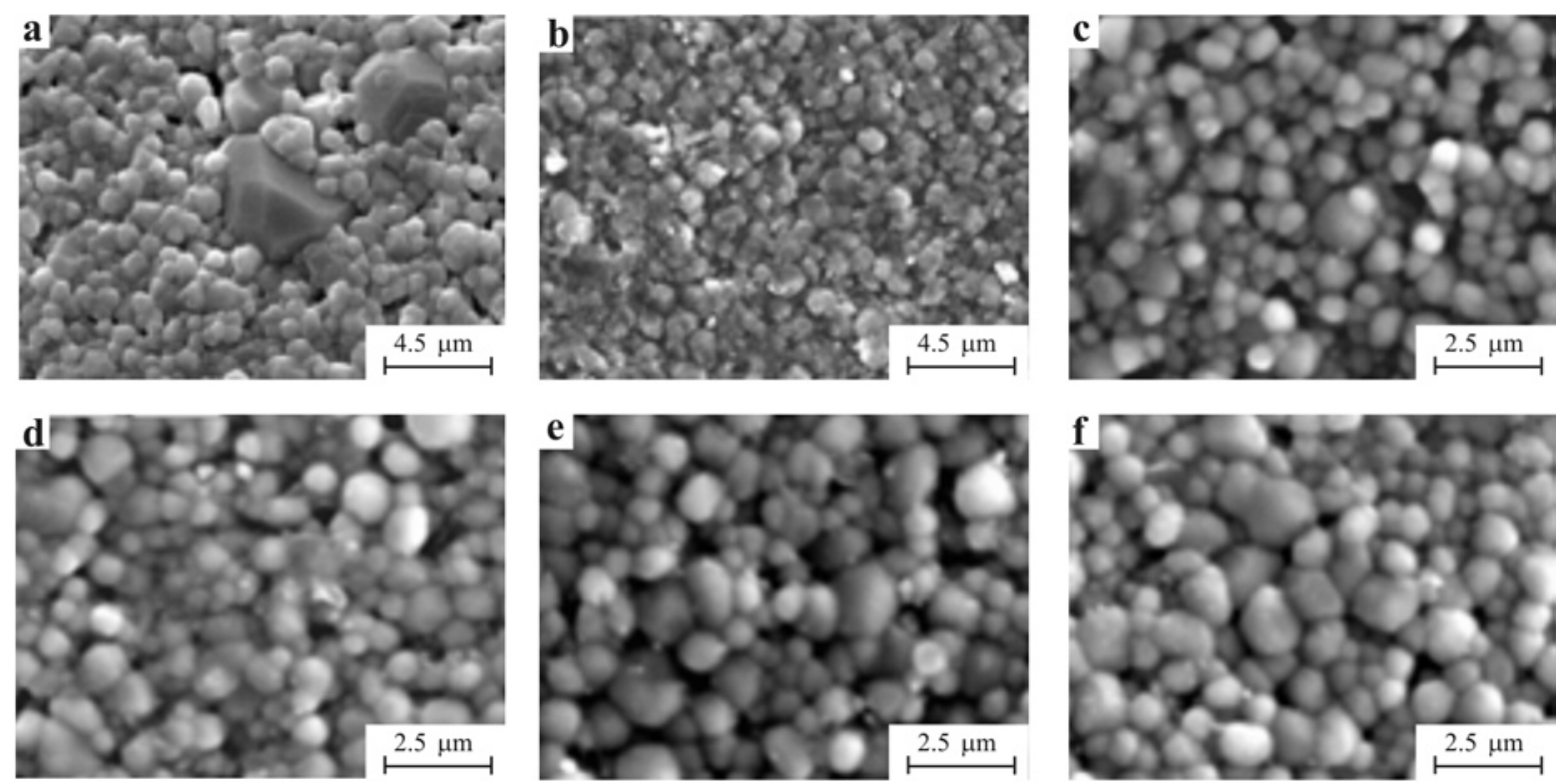

Figure 4: SEM micrographs of BaTiO3 doping with different Dy contents (mol\%): (a) 0, (b) 0.25, (c) 0.75, (d) 1.0, (e) 1.25 (f) 1.5. [Figura 4: Micrografias MEV de BaTiO ${ }_{3}$ dopado com diferentes teores de Dy (mol\%): (a) 0, (b) 0,25, (c) 0,75, (d) 1,0, (e) 1,25, (f) 1,5.] 
Table II - The average grain size and dielectric properties of sample. [Tabela II - Tamanho médio de grão e propriedades dielétricas da amostra.]

\begin{tabular}{lcccccc}
\hline Dy concentration $(\mathrm{mol} \%)$ & 0.0 & 0.25 & 0.75 & 1.00 & 1.25 & 1.50 \\
Average grain size $(\mathrm{nm})$ & 1200 & 800 & 480 & 600 & 750 & 930 \\
Permittivity & 2634 & 2625 & 4108 & 3572 & 3457 & 3145 \\
Breakdown electric field $\left(\mathrm{kV} . \mathrm{mm}^{-1}\right)$ & 2.6 & 2.4 & 3.2 & 3.0 & 2.8 & 2.3 \\
\hline
\end{tabular}

$\mathrm{BaTiO}_{3}$ is decisively influenced by the energy needed to form compensating defects. However no energy is needed for dopants to concentrate at grain boundaries. Thus $\mathrm{Dy}^{3+}$ is rich at or near grain boundaries to restrain abnormal grain growth during sintering, as promotes the formation of $\mathrm{BaTiO}_{3}$ with fine grains and high density. The microstructure of $\mathrm{BaTiO}_{3}$ ceramic doped with Dy at different concentrations (sintered at $1275^{\circ} \mathrm{C}$ ) were shown by the SEM images in Fig. 4 .

The average grain size of samples was evaluated from the SEM images using the interception method and listed in Table II. As a result, abnormal grains were observed in ceramic samples without Dy-doping. The grain size decreased, when Dy-doping concentration is 0.75 mol\%, the grain size reached minimum value, and then increased and many big grains were founded with the increase of Dy concentration. Ohsato reported that there were three stages of substitution of rare earth element in $\mathrm{BaTiO}_{3}[12]$.In the present study three different doping mechanisms can be also proposed according to the testing results including resistivity, lattice parameter and microstructure:

$\mathrm{Ba}^{2+}{ }_{1-\mathrm{x}} \mathrm{Dy}^{3+}{ }_{\mathrm{x}} \mathrm{Ti}^{4+} \mathrm{O}_{3}$, Ba substitution, electron compensation, $\left[\mathrm{Dy}_{\mathrm{Ba}}^{\cdot}\right]=\left[\mathrm{e}^{\prime}\right]$

$\mathrm{Ba}^{2+}{ }_{1-\times / 2} \mathrm{Dy}^{3+}{ }_{\mathrm{x}} \mathrm{Ti}^{4+}{ }_{1-\times / 2} \mathrm{O}_{3}, \mathrm{Ba}$ and Ti substitution,

self-compensation, $\left[\mathrm{Dy}_{\mathrm{Ba}}^{\cdot}{ }^{-}=\left[\mathrm{Dy}_{\mathrm{Ti}}^{\prime}\right]\right.$

$\mathrm{Ba}^{2+} \mathrm{Dy}^{3+}{ }_{\mathrm{x}} \mathrm{Ti}^{4+}{ }_{1-\mathrm{x}} \mathrm{O}_{3-3 \times 2}$, Ti substitution, oxygen vacancy

compensation, $\left[\mathrm{Dy}^{\prime}{ }_{\mathrm{Ti}}\right]=2\left[V_{O}^{\bullet \bullet}\right]$

When Dy content was $0.75 \mathrm{~mol} \%$, the doping mechanism was above (B) shown, the site occupancy ratio to metal vacancy was 1 From Eq $(\mathrm{G})$ :

$$
\frac{\left[\mathrm{Dy}_{\mathrm{Ba}}^{*}\right]}{\left[\mathrm{Dy}_{\mathrm{Ti}}^{\prime}\right]} \propto \frac{\left[\mathrm{V}_{\mathrm{Ba}}^{\prime \prime \prime}\right]}{\left[\mathrm{V}_{\mathrm{Ti}}^{\prime \prime \prime \prime}\right]}
$$

This suggests that all defects concentration is the lowest [13]. Dy could retard the abnormal grain growth during sintering, which caused the grain size was about $480 \mathrm{~nm}$ (Fig. 4 (c)) without abnormal grains. Good microstructure

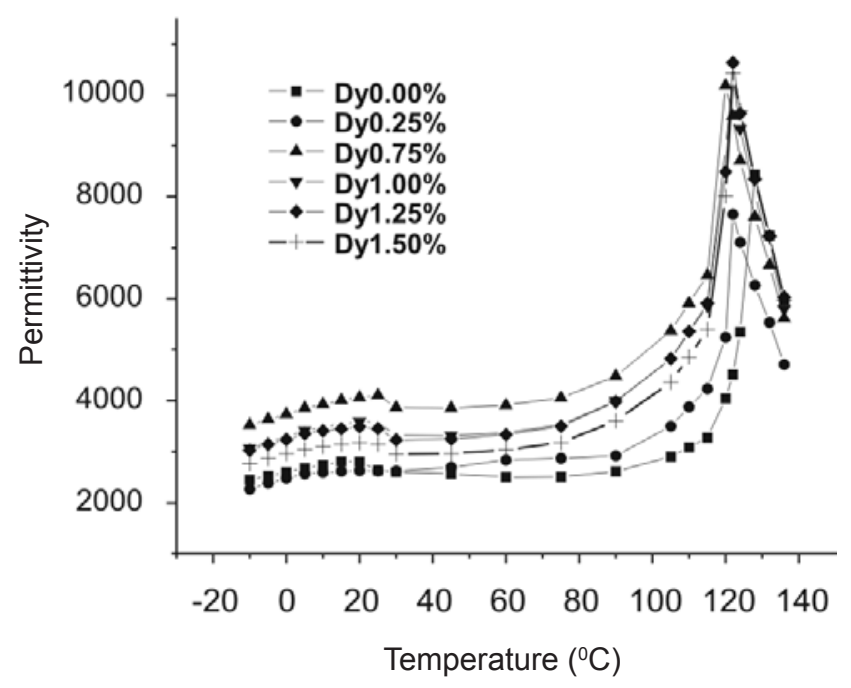

Figure 5: Dielectric properties of dielectric constant of $\mathrm{BaTiO}_{3}$ ceramic doped with different Dy contents.

[Figura 5 : Propriedades dielétricas da constante dielétrica da cerâmica de $\mathrm{BaTiO}_{3}$ dopada com diferentes teores de Dy.]

of ceramic with fine- and homogeneity- grain would lead to good electric properties.

Fig. 5 shows the temperature dependence of the dielectric constant as a function of Dy-doping concentration .It is indicated that the Curie temperature of $\mathrm{BaTiO}_{3}$ ceramic with the Dy-doping concentration in the range of $0-1.5 \mathrm{~mol} \%$ was similar to that of the pure $\mathrm{BaTiO}_{3}$ ceramic. For Dy concentration of $0.75 \mathrm{~mol} \%$, the dielectric constant reaches 4100 . The dielectric constant, insulation resistance, and breakdown field strength are important engineering parameters for highvoltage ceramic capacitors. The temperature coefficient of the capacitance varies from -10 to $10 \%$ within the temperature range of $-15{ }^{\circ} \mathrm{C}-100{ }^{\circ} \mathrm{C}$ calculated from the result of Fig. 5 .

The maximum voltage-withstanding ability of a ceramic capacitor is mainly governed by the microstructure of ceramic, such as uniformity and average size of the grains. According to a theory in Ref [7], breakdown electric field strength of ceramic capacitor rises by $150 \%$ with every $3 \%$ increase of the density of the ceramic. Thus fine grains would promote high-density microstructure of ceramic. The domains are orientable by an externally applied electric field during the course of polarization. Orientation of domains will lead to strain in dielectric ceramics. Moreover, the strength 
of strain increases with the grain size. The breakdown field strength decreases with increasing the grain size of the high density ceramics. the breakdown electric field strength (alternating current) achieves $3.2 \mathrm{kV} / \mathrm{mm}$. These data suggest that our barium titanate could be used in the manufacture of high voltage ceramic capacitors.

\section{CONCLUSION}

The relationship between substitution behaviors and lattice parameters in solid-solubility were studied. The results show that, at a dysprosium concentration of $0.75 \mathrm{~mol} \%$, the abnormal grain growth is inhibited and the lattice parameters of grain rise up to the maximum because of the lowest vacancy concentration. In addition, the finegrain and high density of barium titanate ceramic result in its excellent dielectric properties. The relative dielectric constant $\left(25^{\circ} \mathrm{C}\right)$ reaches to 4100 . The temperature coefficient of the capacitance varies from 10 to $10 \%$ within the temperature range of $-15^{\circ} \mathrm{C}-100$ ${ }^{\circ} \mathrm{C}$, and the breakdown electric field strength (alternating current) achieves $3.2 \mathrm{kVmm}^{-1}$. These data suggest that our barium titanate could be used in the manufacture of high voltage ceramic capacitors.

\section{REFERENCES}

[1] M.-H.Um, H. Kumazawa, J. Mater. Sci. 35 (2000) 1295

[2] Y. Wang, L. Li, J. Qi, Ceram. Int. 28 (2002) 657

[3] W.-H Lee, W. A. Groen, H. S. Chreinema, J. Electroceramics 5 (2000) 31

[4] H. Kishi, N. Kohzu, J. Sugino, J. Eur. Ceram. Soc. 19 (1999) 1043

[5] D. Makovec, Z. Samardzijia, M. Drofenik, , J. Am. Ceram. Soc. 87 (2004) 1324

[6] S. Venigalla, D. J. Clancy, D. V. Miller, Am. Ceram. Soc. Bull.78 (1999) 51-54

[7] A. J. Moulson, J. M. Herbert, Electroceramics, Wiley Press, New York (2003) 345

[8] D. R. Lide, Handbook of Chemistry and Physics , CRC press, New York (2000) 4

[9] Y. Tsur, D. T. Dunbar, C. A. Randall, J. Electroceramics 7 (2001) 25

[10] M. Drofenik, J. Am.Ceram. Soc. 70 (1987) 311

[11] D. Hennings, J. Eur. Ceram. Soc. 21 (2001) 1637

[12] K. Watanabe, H. Ohsato, H. Kishi, Solid State Ionics 108 (1998) 129

[13] Y. Tsur, H. Hitomi, I. Scrymgeour, Jpn. J. Appl. Phys. 40 (2001) 255

(Rec. 02/03/2005, Rev. 12/05/2005, Ac. 03/06/2005) 